\title{
7. The Four Approaches to Measuring Wellbeing
}

\author{
John Hawkins ${ }^{1}$
}

\section{Introduction}

Discussions of the relationship between wellbeing and material progress go back a long way. One of the earliest extant comes from Aristotle:

What is it that we say political science aims at and what is the highest of all goods achievable by action? ... It is happiness, and we identify living well and doing well with being happy...the life of money-making is one undertaken under compulsion, and wealth is evidently not the good we are seeking; for it is merely useful for the sake of something else. ${ }^{2}$

Economic growth in classical times was so slow as to be unobservable to those living and writing at the time. ${ }^{3}$ Rather than writing of social progress, the Ancient Greeks mostly referred to a regression from a previous golden age. ${ }^{4}$ Many regarded the means of achieving contentment to lie in the reduction of wants rather than an increase in output. ${ }^{5}$ Across the world Confucian, Taoist and Buddhist theorists were similarly disinterested in expanding production. ${ }^{6}$ The idea of economic progress only became commonly discussed with the advent of the French Enlightenment and the work of Adam Smith. ${ }^{7}$ This was also the time when the industrial revolution had led to a marked acceleration in economic output. ${ }^{8}$

\footnotetext{
1 Thanks are due to Alex Millmow, Andrew Podger and other participants at the ASSA Crawford School Roundtable on Economic Growth and Wellbeing, and to an anonymous referee, for helpful comments. Views expressed are those of the author and not necessarily shared by organisations to which he is affiliated.

2 Aristotle (c 330BC, book 1). The Greek word eudaimonia is translated as either happiness or wellbeing

3 Angus Maddison (2001, p 28) believes that between 0 and $1000 \mathrm{CE}$ there was no average real per capita growth in GDP in either Europe or Asia.

4 This tradition goes back at least to Hesiod. Furthermore, when they did refer to increases in national wealth, the classical writers often thought it a corrupting influence; Ambirijan (1997: 33). Plato disdains avidity and cupidity, warning it leads to a gap between the citizens; Baeck (1997: 155).

5 Epicurus and Diogenes were perhaps the leading exponents of this view. It was more recently expounded by Ghandhi; Dasgupta (1993, chapter 9).

$6 \mathrm{Hu}(1988: 47,214-5)$.

7 Pollard (1968). Arguably the first writer to address economic growth was Sir Josiah Child in the seventeenth century; Spiegel (1971: 151).

8 Angus Maddison (2001: 126) estimates that between 1820 and 1870 real per capita output grew by annual average of around one per cent in Western Europe. The peak growth period was over four per cent in Western Europe and over eight per cent in Japan during 1950-1973.
} 
Other than some pioneering estimates in the seventeenth century, ${ }^{9}$ it was centuries before discussions of national income could be informed by statistics. ${ }^{10}$ Arguably the first official national income estimates were the work of the pioneering New South Wales statistician Timothy Coghlan, published annually starting from Coghlan (1887). ${ }^{11}$ But Coghlan's work, far ahead of its time, was not sustained. It was not until the Keynesian revolution that interest in compiling national accounts became widespread. Much of the early development occurred in the run-up to and early stages of World War II and so the focus was on output that could be diverted to the war effort. ${ }^{12}$ Amongst the pioneers were Simon Kuznets and the Australian economists Colin Clark and James Sutcliffe. ${ }^{13}$

The first official set of national accounts was prepared by the then Commonwealth Bureau of Census and Statistics and published in the 1945 budget papers as Estimates of National Income and Public Authority Income and Expenditure. The first macroeconomic forecasts for Australia appeared in some early drafts of the White Paper on Full Employment in 1945 but not in its final published version. ${ }^{14}$ The annual, and then quarterly, national accounts attracted increasing public attention. When some questioned the desirability of economic growth, Treasury commissioned a team led by Ian Castles to address the issue. ${ }^{15}$ After moving to the ABS, Castles initiated work on broader measures of living standards that became Measures of Australia's Progress (see below). ${ }^{16}$

\section{Concerns about sustainability}

But even while economists were starting to measure national income, there were some questioning the sustainability of growth. Malthus in the nineteenth century expressed concern that economic growth, in particular population growth, would tend to outstrip resources, notably farmland. He warned that the conflict was likely to be resolved by population being limited by starvation.

\footnotetext{
9 Sir William Petty (1665), a founding member of the Royal Society and friend of Samuel Pepys, estimated the national income of the United Kingdom and argued it was expanding; Deane and Cole (1969); Medema and Samuels (2003: 45-56), Rothbard (1995: 296-302); Spiegel (1971: 122-135). Ian Castles (1998) regards this as the first national income estimate. Gregory King (1688) made a more detailed attempt and there were also estimates compiled for France a little later by Boisguillebert and Vauban; Australian Bureau of Statistics (2000: 2).

10 Cairncross (1988) gives a short history.

11 See Arndt (1949), Clark and Crawford (1938: 53-55), Goodwin (1966: 473-474) and Haig (2001, 2006) for an account.

12 Daly and Cobb (1989: 70).

13 Clark (1932) on the United Kingdom and Clark and Crawford (1938) on Australia; Sutcliffe (1926). Coombs

(1944) presented some 'semi-official' national income estimates for 1938-39 and projections for 1947-48.

14 Cornish (1981).

15 Treasury (1973).

16 Podger (2010).
} 
Arguably the first rigorous analysis that looked at natural resources as a constraint on economic growth was Jevons' book The Coal Question published in $1865 .{ }^{17}$ In it he presents projections indicating that coal could be exhausted by 1970, but warns that well before then the increasing price could slow economic activity. He examined the prospects for some of the renewable energy technologies of the day - windmills and waterwheels. Jevons warns of the danger of basing an economy on an exhaustible energy source; as he puts it 'encouraging a growth of industry which must prove unstable and perhaps involve all things in its fall'. ${ }^{18}$

Neither Malthus' nor Jevons' dire predictions came to pass in the way they feared. Both had underestimated the pace of technological innovation and the role that price signals triggered by scarcity could play in encouraging innovation. Nonetheless, as Kenneth Boulding once observed 'anyone who believes that exponential growth can go on forever in a finite world is either a madman or an economist'. ${ }^{19}$ There are key issues of sustainability today, with climate change and peak oil probably the two most prominent aspects.

\section{Modern attitudes to measuring wellbeing: Four approaches}

While GDP and national income were never designed as a measure of wellbeing, and statisticians 'never pretended'20 they were, they were often given this interpretation. But increasingly their unsuitability for this purpose was recognised. Arthur Pigou, the founder of modern welfare economics, argued that it is not just increases in national income that constituted improvements in national wellbeing; in particular he carefully distinguished whether the increased income was solely reflecting population growth, how it was distributed and how much it fluctuated..$^{21}$ Moses Ambramovitz concluded:

We must be highly sceptical of the view that long term changes in the rate of growth of welfare can be gauged even roughly from changes in the rate of growth of output. ${ }^{22}$

A common argument runs that GDP per capita can hardly be the benchmark for achieving community satisfaction when:

17 William Stanley Jevons was professor of political economy at University College, London and an important contributor to the 'marginal revolution' in economics. He also built a 'logic piano', a proto-computer.

18 As a young man Jevons had worked at the Mint in Sydney for a few years. Ian Castles successfully lobbied the Powerhouse Museum to commemorate the work by Jevons in a display. See Castles (2004).

19 Cited in Brown and Singer (1996: 126). Boulding was himself an economist.

20 Trewin (1998: 110).

21 Pigou (1920: 82-92), discussed further in Spiegel (1971: 572) and Vaggi and Groenewegen (2003: 274-275).

22 Ambramowitz (1959: 21). 
In the UK the percentage reporting themselves 'very happy' declined from 52 per cent in 1957 to 36 per cent today, even though real incomes have more than doubled. ${ }^{23}$

There are various anomalies caused by GDP being focused on market activities. The classic example is that a man who marries his housekeeper lowers GDP. ${ }^{24}$ Downhill skiing is included in GDP (as lift tickets are a market transaction) but cross-country skiing is not. Earthquakes can boost GDP because the destruction of buildings does not subtract from GDP but their reconstruction can add to it.

Robert Kennedy famously remarked:

...the gross national product does not allow for the health of our children, the quality of their education, or the joy of their play. It does not include the beauty of our poetry or the strength of our marriages; the intelligence of our public debate or the integrity of our public officials. It measures neither our wit nor our courage; neither our wisdom nor our learning; neither our compassion nor our devotion to our country; it measures everything in short, except that which makes life worthwhile. ${ }^{25}$

Less poetically, but at the same time, an Australian treasurer was also talking about the need for aiming at broader measures of economic wellbeing, including clean air, the physical environment, an equitable distribution of income and the needs of the disadvantaged:

...we must not fall too readily to exclusive worship at the altar of GNP... our prime concern should always be the social welfare of the community as a whole. ${ }^{26}$

A parliamentary colleague, soon also to be treasurer, argued for a focus on 'gross national wellbeing' and warned that: ...pre-occupation with economic growth is an over simplistic and misconceived approach. ${ }^{27}$

Bob Brown gave the following further examples:

If I feed myself by growing vegetables in my backyard, using household waste as compost, I contribute nothing to the GNP. If I sell the vegetables and use the money to buy hamburgers, I am increasing GNP. If the

\footnotetext{
23 Jackson, (2009: 40). This 'Easterlin paradox' is widely accepted although some writers such as Stevenson and Wolfers (2008) have questioned it.

24 Pigou (1920).

25 Address at University of Kansas, 18 March 1968, Cited by Australian Bureau of Statistics (2010).

26 Bury (1969: 7-8).

27 Lynch (1973).
} 
crime rate rises and people start stealing my vegetables so that I have to pay someone to build an ugly barbed-wire fence around them, GNP increases still further. ${ }^{28}$

Indeed to its harshest critics GDP gives a 'Grossly Distorted Picture'29 of progress towards improving wellbeing. While Treasury argued in the 1970s that GDP was a good proxy for welfare, ${ }^{30}$ it now has its own 'wellbeing framework' in which 'consumption possibilities' are only one of five components.

These concerns have led to a desire for alternative measures that would give a better idea of whether the nation is making true progress in improving wellbeing than does GDP. There are essentially four approaches; adjusting GDP to make it more suitable, replacing it with a 'dashboard' of alternative indicators, weighting these alternative indicators to form a composite indicator, and using peoples' own reported assessments of their well-being.

\section{Adjusted GDP}

Sir John Hicks defined income as follows:

...we ought to define a man's income as the maximum value which he can consume during a week and still expect to be as well off at the end of the week as he was at the beginning. ${ }^{31}$

One approach to get closer to a measure of wellbeing is to adjust the published GDP to get closer to Hick's definition. It is worth noting that on Hicks' definition, 'sustainable income' is almost a tautology; Hicksian income is maximum sustainable consumption. ${ }^{32}$

Applying Hicks' approach to national income would deduct from GDP a broad measure of depreciation. Statisticians publish net national product (NDP), which is GDP less depreciation of the produced capital stock. When there is little structural change, movements in GDP and NDP tend to be quite similar. But

\footnotetext{
28 Brown and Singer, (1996: 126).

29 The Economist, 9 February 2006.

30 The paper, Treasury (1973: 6), while anonymous, was primarily the work of Ian Castles. It said 'obviously the pursuit of growth for its own sake misses the point: the aim must be to improve the welfare of the community. Policies directed to this latter end are likely in fact to lead to increases in the real output of the economic system per head of population and can thus fairly be described - without abuse of language - as policies for economic growth'. In Castles (1998: 353) his view was that 'I do not share the commonly held view that individual decisions are affected by the particular definition of GDP that has been adopted by the world's official statisticians...the view that decision-makers are misled is rarely supported by evidence. In my view, the GDP is a valuable and necessary, but not sufficient, measure of material progress'.

31 Hicks, (1946: 172).

32 Hamilton and Denniss (2000: 7).
} 
over the past couple of decades the IT sector, subject to very high depreciation rates, has become a more significant share of the economy and so NDP has grown slower than GDP.

GDP includes the value of production in the economy but not all this accrues to the residents. In economies with substantial amounts of foreign ownership (or who own substantial assets in foreign countries) there can be significant differences between GDP and Gross National Product (GNP).

An increase in GNP or NDP that just arises from inflation does not represent an improvement in wellbeing. Nor is the average citizen better off if GNP or NDP rises but the population is increasing more quickly.

In terms of measuring wellbeing of residents in the country, real net national disposable income per capita is probably the best measure from the national accounts as currently compiled. From 2003-04 to 2011-12 it grew at an annual average rate of 2.3 per cent, considerably faster than the 1.3 per cent growth rate for GDP per capita, mostly reflecting the sharp rise in Australia's terms of trade.

Its major remaining weakness is that the depreciation deduction is limited to only produced capital, (e.g. equipment and buildings), not a broader concept of capital encompassing natural capital (e.g. forests, minerals) or ideally also environmental capital (e.g. air quality, biodiversity), human capital (e.g. education, health) and social capital (e.g. social organisations, community trust). The difficulty is that these other forms of capital are harder to measure than produced capital, which can be estimated by either surveying businesses or accumulating investment data (and applying assumed depreciation rates).

Some studies have attempted to augment GDP in other ways. For example, the coverage could be expanded beyond market activities, for example by valuing production in the home: services such as cooking, cleaning and child-minding that could potentially be done by paid workers instead. These can be valued either at the rate external workers are paid for these services or at a higher 'opportunity cost' (say, the average salary).

Conversely there are some things that are counted in GDP that arguably should not be if the purpose is to measure wellbeing. Surveys have shown that 'commuting to work is the daily activity that gives the least amount of enjoyment, with commuting home from work only marginally more enjoyable'.$^{33}$ Furthermore, commuting could be argued to be an intermediate input rather than a final act of consumption. For these reasons the costs of commuting are sometimes deducted from GDP in constructing wellbeing measures. Similar arguments are made about advertising expenditure. 
The general result of these exercises is that at low national incomes GDP and more sophisticated measures of genuine progress move in similar ways but beyond a threshold GDP growth translates into much smaller (on some accounts no) improvements in wellbeing. ${ }^{34}$ Some examples of these studies follow.

Nordhaus and Tobin's (1972) 'measure of economic welfare' (MEW) was an early attempt at modifying GDP to derive a better measure of true progress. ${ }^{35}$ Activities regarded as not directly sources of utility in themselves but regrettably necessary inputs (e.g. expenditure on prisons or commuting to work) were treated as intermediate rather than final products and so excluded from GDP. They then added monetary estimates of activities (e.g. leisure, work at home) that do add to wellbeing. ${ }^{36}$ Their MEW measure grew at an annual rate of 1.1 per cent from 1929 to 1965 , compared to 1.7 per cent for NNP. ${ }^{37}$

Daly and Cobb's (1989) Index of Sustainable Economic Welfare also excludes 'regrettably necessary expenditures'. They construct their index for the US by first dividing household consumption by an index of distributional inequality. They then add household services (cooking, cleaning, child care), services from household durables, government provision of roads, and half of government spending on higher education and some government spending on health. They then subtract household spending on durables, most private spending on education and health, most advertising expenditure, expenditure on commuting, an estimate of the costs of urbanisation, cost of motor vehicle accidents, and the costs of water, air and noise pollution. They then make deductions for activities which undermine the sustainability of the natural resources base; the loss of farmland and wetlands, the depletion of non-renewable resources and long-term environmental damage (assumed proportional to consumption of fossil fuels and nuclear energy). They then subtract the amount of new capital required to maintain the amount of capital per worker. Finally they add the change in the US net international asset position. ${ }^{38}$ The index grows during the $1950 \mathrm{~s}$ and 1960s, flattens out in the 1970s and declines in the 1980s, with trends in inequality one of the main drivers. ${ }^{39}$

There have also been attempts to construct measures of 'Green GDP' by taking into account the consumption of natural capital, comprising resource depletion

\footnotetext{
34 Stiglitz, Sen and Fitoussi (2010: 105).

35 The authors modestly only claimed MEW was a 'primitive and experimental' attempt.

36 This can make a significant difference. Household production is equivalent to about a third of conventionally measured GDP in Finland, France and the US while including a value on leisure roughly doubles net household income; Stiglitz, Sen and Fitoussi (2010: 52-53).

37 Nordhaus and Tobin (1972: 13).

38 For a range of pragmatic and conceptual reasons they do not include some of the adjustments made by others. For example, they are sufficiently unconvinced that health and education add much to productivity in advanced economies that they do not include them in human capital calculations. They believe there are many measurement problems with leisure, so, in the absence of any significant drop in average hours worked, they leave it out. They considered excluding spending on junk food, tobacco and pornography but decided this would be too subjectively judgemental; Daly and Cobb, (1989: 402-442).

39 Daly and Cobb, (1989: 453-454).
} 
and environmental degradation, but they have encountered resistance. President Clinton's 1993 Earth Day speech said that 'Green GDP measures would incorporate changes in the natural environment into the calculations of national income and wealth' but congressional opposition delayed the project. ${ }^{40}$ The Chinese government attempted to introduce a 'green GDP' measure which adjusted GDP for pollution, environmental degradation and resource depletion. The initiative was short-lived, however, as the leaders of provinces dependent on heavy industry resented the reductions in their reported growth rates. ${ }^{41}$

The Australia Institute (AI) presented a Genuine Progress Indicator in 1997, which they updated in 2000. ${ }^{42}$ The main features of the GPI which distinguished it from GDP were accounting for distribution, acknowledging household work, excluding defensive expenditures and accounting for depreciation of built and natural capital. The AI also deducted a proportion of spending on advertising as much of it does not contribute to wellbeing; 'many advertisements are designed to be persuasive rather than informative, creating new needs rather than fulfilling existing ones'. Unlike some similar exercises the GPI does not include the value of leisure, but does deduct the costs of overwork. The AI's GPI per capita increased over 1950-2000 but at a slower rate than did GDP (see Figure 1).

Lateral Economics developed a measure of short-term movements in Australian wellbeing in 2011, sponsored by the Sydney Morning Herald and The Age. ${ }^{43}$ It extends the national accounts by incorporating the increase and depreciation of natural capital and human capital, through accounting for factors such as minerals discoveries, mining, education and long-term unemployment. The Herald Age Lateral Economics index (HALE) is calculated by adjusting real net national income from the national accounts. As the extent of leisure and voluntary work do not fluctuate that much over short time periods, HALE does not attempt to measure them. Congestion costs are hard to measure so no adjustment is made for them. There are adjustments for the distribution of income, based on evidence about how happiness is more sensitive to income increases at lower income levels. Mental health and obesity, and under- or over-work, detract from welfare and lead to lower values of the HALE index. Discoveries of new minerals resources are added in and depletions subtracted. Over the period 2005-2010 the HALE index grew faster than real GDP, reflecting the increase in university students and therefore increased human capital.

40 Nordhaus Panel on Integrated Environmental and Economic Accounting, (1999: 16).

41 Wenzel (2009: 40-41).

42 Hamilton and Denniss (2000).

43 The Herald/Age-Lateral Economics Index of Australia's Wellbeing, December 2011. 


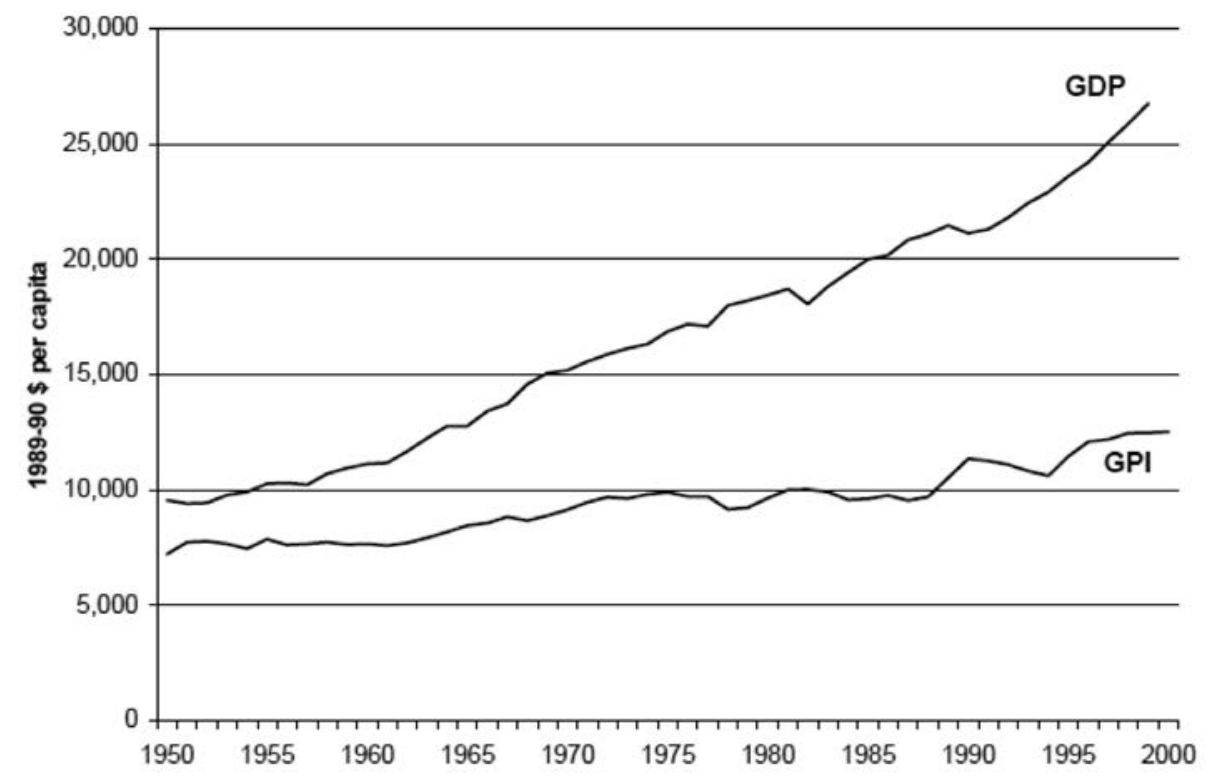

Figure 1 GDP and GPI per capita, 1950-2000

Source: ABS: 2012b.

A review of such measures for half a dozen developed economies concluded that over decades:

All show a similar trend ... increasing with GDP (but sometimes at a lower rate) up to the 1970s, then levelling off or falling away while GDP continues to climb. ${ }^{44}$

\section{Dashboard indicators}

A second approach is to present a 'dashboard' or suite of indicators of various aspects of wellbeing, without attempting to condense them into a single indicator. The commonly used analogy is that when driving you are interested in the car's speed, the distance you have travelled and the amount of petrol remaining in the tank but (while the three measures are not unrelated) a single indicator that added them together would be useless.

This approach has been adopted by the ABS in Measures of Australia's Progress, first published in $2002 .{ }^{45}$ This is a means of combining subjective and objective data, much of which are hard to reduce to a common denominator such as dollar values. The 2012 dashboard is show below. 

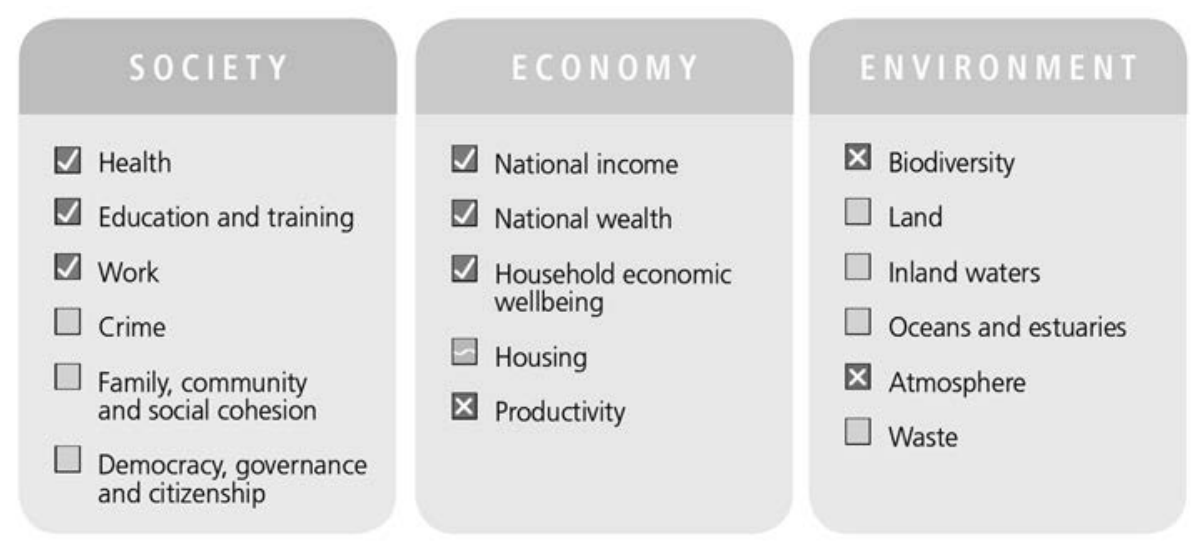

\section{Legend:}

$\checkmark$ Progress has generally been made in this headline indicator compared with ten years ago.

$\mathbf{X}$ This headline indicator has generally regressed compared with ten years ago.

There has been no significant movement in this headline indicator compared with ten years ago.

There is either no headline indicator for this area of progress or no time series.

\section{Figure 2 ABS Measures of Australia's Progress}

Source: ABS: 2012b.

\section{Composite indices}

A third approach is to present composite indices, usually including GDP, but which also give weight to other aspects of wellbeing. The United Nations' Human Development Index, which combines education and life expectancy with per capita GDP, is a prominent example. ${ }^{46}$ (Australia ranks second only to Norway on this measure.) The challenge with this class of measures is the arbitrariness of the weighting - how many extra dollars in average income is worth the same as an extra year in life expectancy?

Jones and Klenow (2010) combine data on consumption, leisure, inequality and mortality and try to weight them by their contribution to expected utility. Their measure turns out to be highly correlated with per capita GDP.

The Canadian Index of Wellbeing is another such index, giving equal weight to eight aspects: living standards, healthy populations, community vitality, democratic engagement, leisure and culture, time use, education, and the environment. 
The Lagatum institute compiles an index of prosperity, based on indicators of entrepreneurship, economic performance, personal freedom, social capital, governance, health, safety and education. In 2012 Switzerland, Norway and Singapore are ranked the highest while Australia ranks tenth (doing particularly well on education, personal freedom and social capital).

Bhutan is known for aiming at, and attempting to base policy decisions on, 'Gross National Happiness' which encompasses four pillars of sustainable development, cultural values, the natural environment and good governance. ${ }^{47}$

The Australian National Development Index project, launched in May 2010, is aiming to create such an index with weights reflecting a consensus on the importance of various components in wellbeing. ${ }^{48}$

The ABS are sceptical of suggestions that the indicators in their dashboard could be weighted to form such an index:

We prefer an approach where there is a dashboard, and where there are a range of social, economic and environmental indicators that people can look at and come to their own judgement about how they might want to weight those various measures of progress in Australia's society, and about whether they think Australian society is progressing across those key areas of interest... The difficulty is recognised by all of the people involved in these indexes - the difficulty of trying to weight those things in a way that reflects some sort of average view in Australian society of the importance of those things. ${ }^{49}$

As Lateral Economics comment:

...pure composite indices appear to have made negligible progress in dealing with the incommensurability of the various aspects of wellbeing, leading most of them to simply posit that each aspect is equally important..$^{50}$

Ian Castles once said:

Composite indicators are unsatisfactory because they imply there is a single answer to the question of whether life in a particular country is getting better or worse. But there can be no single answer. ${ }^{51}$

As another former Australian Statistician commented:

\footnotetext{
47 Kelly (2012).

48 Allen Consulting Group, What Kind of Australia Do We Want?

49 Trevor Sutton, Acting Australian Statistician, Senate Economics Committee Estimates Draft Hansard, 17 October 2012: 132-133.

50 The Herald/Age-Lateral Economics Index of Australia's Wellbeing, December 2011: x.

51 Castles (1998: 352).
} 
To be useful, indicators must have status: they need to be supported as valid by a wide body of Australians and preferably be underpinned by an international standard..$^{52}$

On the other hand, the media seem to crave such a single indicator and in the absence of anything better being compiled will continue to use GDP. A composite index, or adjusted GDP:

Is, in part, about changing the values of society...[and] the research community needs to be pushed along a bit in this area...there is considerable value in an aggregate index that attracts publicity and attention. $^{53}$

One response is to present the dashboard in such a way that users can readily assign their own weights to produce an index. This has been done by the OCED with their Better Life Index, available at www.oecdbetterlifeindex.org.

If such websites retain the weights selected by users, then over time they can reflect the average opinion of those users, which may be a reasonable set of weights to apply to form a composite index. This is a feature of the OECD website and based on these weights Australia, Canada and Sweden have the highest wellbeing of any OECD countries. ${ }^{54}$

The ABS themselves have gathered some information, summarised in the cloud below, from their consultations about improving the Measures of Australia's Progress, on what things are more valued by the community. index that is rough and ready, and certainly subjective, can play an important role in focusing and generating discussion on poverty'. 


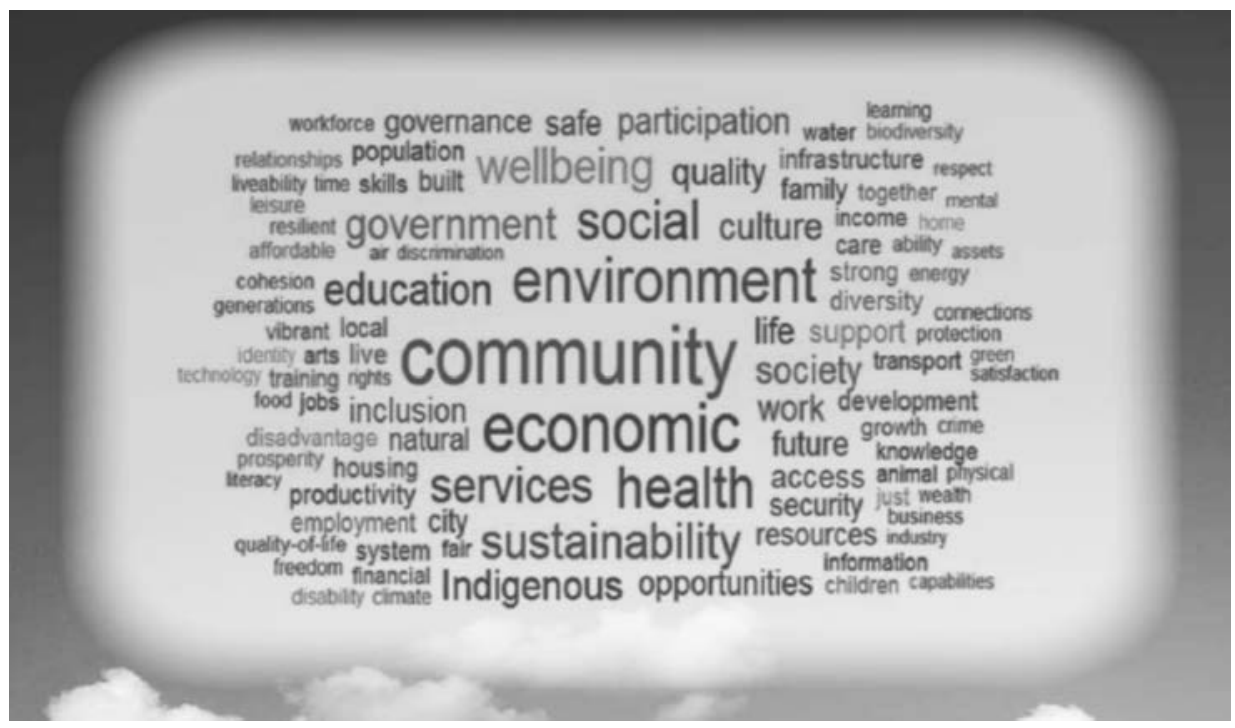

Figure 3 ABS cloud analysis of consultation on measuring progress

Please note: This word cloud represents the range of ideas expressed during the MAP consultations. The size of the words represents how often they were raised.

Source: Australian Bureau of Statistics (2012: 5).

A relatively simple composite index that has attracted some attention is Veenhoven's 'happy life-expectancy'; a multiple of life expectancy with a survey-based measure of happiness which he shows is 'systematically higher in nations that are most affluent, free, equal, educated and harmonious' ${ }^{55}$

\section{Subjective happiness indices}

A fourth approach is to ask people to assess subjectively their feelings of wellbeing or satisfaction with their life. Economists had formerly regarded such things as essentially unable to be measured properly (notwithstanding the use made of the concept of 'utility' in economic theorising). The OECD recently assessed, however, that 'an increasing body of evidence has supported the view that it is possible to gather valid measures of subjective wellbeing based on surveys'.$^{56}$ It has been noted that questions about subjective wellbeing get high response rates, consistent replies, show expected relationships with other variables and match well with biological indications of happiness or stress and assessments made by friends. They also predict behaviours such as suicide and sleep quality and outcomes such as income, marital status and mortality. ${ }^{57}$

55 Veenhoven (1996: 1).

56 OECD, (2011: 266).

57 OECD, (2011: 266-7); Clark, Fritjers and Shields (2008: 116-117); Kreuger et al (2009: 22-24). 
Canada is the only country with a long run of official data on life satisfaction but it is now collected regularly by official agencies in New Zealand, France and Italy as well. (The collection of subjective assessments of wellbeing by national statistical agencies was recommended in the report commissioned by then president Sarkozy). ${ }^{58}$ Gallup and Eurobarometer provide data from a broader range of countries. At an individual level, within a given country in a given year, there tends to be a strong correlation between income and satisfaction, but the correlation is much weaker across countries and across time. In particular, increases in average incomes seem to have resulted in little increase in average satisfaction. This is known as the 'Easterlin paradox'. ${ }^{59}$ Studies that tried to explain the Easterlin paradox by including 'omitted' variables found that most other factors (e.g. life expectancy, hours worked, health, crime) that might have been expected to increase surveyed happiness did not do so, making the paradox even more puzzling. ${ }^{60}$

The most common explanations are that it is relative rather than absolute income that is most relevant in determining whether people are happy (at least over a certain income threshold) and that while an increase in income initially makes people happy they soon adapt their expectations and their happiness reverts to the previous level. ${ }^{61}$

The ABS conducted surveys of life satisfaction in 2001 and $2010,{ }^{62}$ but has not chosen to make it a regular component of Measures of Australia's Progress.

Australian Unity, in conjunction with Deakin University's Centre on Quality of Life, has been producing the Australian Unity Wellbeing Index since 2001. ${ }^{63}$ It is based on a telephone survey of 2,000 Australians. This measures how satisfied people are with their own lives (covering health, personal relationships, safety, standard of living, achieving, community connectedness and future security) and with life in Australia in general (covering the economy, environment, social conditions, governance, business and national security). In recent surveys wellbeing generally was found to rise with income up to around $\$ 100,000$ but not thereafter. As with similar studies overseas there has been no significant improvement in average life satisfaction since 2001 despite average real incomes having risen over 20 per cent since then. This is consistent with an observed

\footnotetext{
58 Stiglitz, Sen and Fitoussi (2010: 93).

59 Easterlin (1974). The data showing the paradox has been questioned by Stevenson and Wolfers (2008).

60 Clark, Fritjers and Shields (2008: 114-115).

61 Clark, Fritjers and Shields (2008); OECD (2011: 271). The adaption process is sometimes called the 'hedonic treadmill'. While a recent concept, warnings of the dangers of envy go back at least to Buddha; Dasgupta (1993: 5).

62 The latter in General Social Survey: Summary Results, ABS 4159.0, September 2011.

63 The latest report, referring to April 2012, can be found at http://www.australianunitycorporate.com.au/ community/auwi/Pages/default.aspx.
} 
tendency for most improvements in objective measures of wellbeing to have only temporary impacts on satisfaction which consistently returns to its average level, a phenomenon labelled 'subjective wellbeing homeostasis'.

The NAB Quarterly Australian Wellbeing Index provides another such measure. $\mathrm{NAB}$ also surveys consumers to produce an index of consumer anxiety.

The Melbourne Institute's HILDA survey also includes life satisfaction questions which it has been asking since 2001. ${ }^{64}$ It differs from most indices in being 'longitudinal'; that is the same people are questioned in each survey. It also shows that average life satisfaction has remained essentially the same despite increases in average real incomes.

\section{Conclusion}

This short survey of the four main approaches has shown there is no single agreed way of measuring wellbeing. Perhaps until there is some degree of agreement, commentators will continue to use real GDP per capita despite its widely acknowledged limitations. It does at least have the virtue of being compiled on a consistent basis across time and across countries and is at least correlated with such objective characteristics of wellbeing as health, life expectancy and the environment.

While many policymakers and academics are keen for better indicators of wellbeing, and there is an increasing interest in sustainability issues and the interaction between inequality and wellbeing, there are some powerful vested interests that prefer not to have questioned whether their activities are truly benefiting overall sustainable wellbeing. This seems likely to ensure that wellbeing remains a complex and controversial concept.

\section{References}

Ambirajan S (1997). 'The concepts of happiness, ethics and economic values in ancient economic thought', in B Price (ed) Ancient Economic Thought, Routledge, London: 19-42.

Ambramovitz M (1959). 'The welfare interpretation of secular trends in national income and product', in The Allocation of Economic Resources, Stanford University Press, pp 1-22.

64 http://www.melbourneinstitute.com/downloads/hilda/Stat_Report/statreport-v7-2012.pdf. 
Measuring and Promoting Wellbeing: How Important is Economic Growth?

Aristotle (c 330 BC). Nicomachean Ethics, translated by Ross, W, Oxford University Press, 1925.

Arndt H (1949). 'A pioneer of national income estimates', Economic Journal, vol 59, no 236, December: 616-625.

Australian Bureau of Statistics (2010). Measures of Australia's Progress, 2010.

Australian Bureau of Statistics (2012). Measures of Australia's Progress: Aspirations for Our Nation: A Conversation with Australians About Progress.

Baeck L (1997). 'Greek economic thought' in B Price (ed) Ancient Economic Thought, Routledge, London: 146-171.

Brown B and Singer P (1996). The Greens, Text Publishing, Melbourne.

Bury L (1969). 'Policies for growth in the seventies', address to the Economic Society of Victoria, 7 May.

Cairncross A (1988). 'The development of economic statistics as an influence on theory and policy' in D Ironmonger, J Perkins and VH Tran (eds) National Income and Economic Progress: Essays in Honour of Colin Clark, Macmillan Press, London: 11-20.

Castles I (1998) 'Measuring economic progress: from political arithmetic to social accounts', 8th Colin Clark memorial lecture, University of Queensland Department of Economics Discussion Paper 243, October.

Castles I (2004). ' The Curious Economist: William Stanley Jevons in Sydney', address at Powerhouse Museum, 28 October.

Clark A, Fritjers P and Shields M (2008). 'Relative income, happiness, and utility: an explanation for the Easterlin paradox and other puzzles', Journal of Economic Literature, vol 46, no 1: 95-144.

Clark C (1932). The National Income 1924-1931, Macmillan, London.

Clark C and Crawford J (1938). The National Income of Australia, Angus \& Robertson.

Coghlan T (1887). Wealth and Progress in New South Wales, Government printer, Sydney.

Coombs H (1944). 'Problems of a high employment economy', Joseph Fisher Lecture in Commerce, University of Adelaide, 29 June, Hassell Press.

Cornish S (1981). 'Full employment in Australia: the genesis of a white paper', ANU Research Paper in Economic History, no. 1. 
Dasgupta A (1993). A History of Indian Economic Thought, Routledge, London.

Deane P and Cole W (1969). British Economic Growth 1688-1959, Cambridge University Press.

Easterlin R (1974). 'Does economic growth improve the human lot? Some empirical evidence?' in P David and M Reder (eds) Nations and Households in Economic Growth: 89-125.

Eckersley R (1998). 'Perspectives on progress: economic growth, quality of life and ecological sustainability', in R Eckersley (ed) Measuring Progress, CSIRO publishing: 3-34.

Goodwin C (1966). Economic Enquiry in Australia, Duke University Press.

Gregory R (1998). 'Summing up', in R Eckersley (ed) Measuring Progress, CSIRO publishing: 365-370.

Haig B (2001). 'First national accounting estimates', unpublished paper, March, Australian National University.

Haig B (2006). 'Sir Timothy Coghlan and the development of national accounts', History of Political Economy, Summer, vol 38, no 2: 339-375.

Hamilton C and Denniss R (2000) 'Tracking well-being in Australia: the Genuine Progress Indicator 2000', Australia Institute Discussion Papers, no 35, December.

Hicks J (1946). Value and Capital, London.

Hu J (1988). A Concise History of Chinese Economic Thought, Foreign Language Press, Beijing.

Jackson T (2009). Prosperity Without Growth, Earthscan, London.

Jevons WS (1865). The Coal Question: an Inquiry Concerning the Progress of the Nation and the Possible Exhaustion of our Coal-mines, Macmillan \& Co, London.

Kelly A (2012). 'Gross national happiness: a tiny state's big idea that could change the world', Guardian Weekly, 7 December: 9.

King G (1688). Two Tracts, edited by George Barnett, 1936.

Kreuger A, D Kahneman, D Schkade, N Schwarz and A Stone, 'National time accounting: the currency of life', in A Kreuger (ed) Measuring the Subjective Well-being of Nations, University of Chicago Press.

Lynch P (1973). 'The Liberal Way', Alfred Deakin Lecture (reprinted in Buckley, B 1991 Lynched, Salzburg Publishing, Melbourne). 
Measuring and Promoting Wellbeing: How Important is Economic Growth?

Maddison A (2001). The World Economy: a Millennial Perspective, OECD, Paris.

Medema S and Smauels W (2003). The History of Economic Thought: a Reader, Routledge, London.

Nordhaus W and Tobin J (1972). 'Is growth obsolete?', in Nordhaus W and Tobin J (ed) Economic Research: Retrospect and Prospect, Volume 5: Economic Growth, NBER: 1-80.

Nordhaus Panel on Integrated Environmental and Economic Accounting, 1999, Nature's Numbers,

OECD 2011, How's Life? Measuring Well-being, Paris.

Petty W (1665). Verbum Sapienti.

Pigou A (1920). The Economics of Welfare, $4^{\text {th }}$ edition, 1960, Macmillan, London.

Podger A (2010). 'Adviser helped steer economic reforms' [obituary of Ian Castles], Canberra Times, 13 August.

Pollard S (1968). The Idea of Progress, CA Watts, London.

Rothbard M (1995). Economic Thought Before Adam Smith, Ludwig von Mises Institute.

Spiegel H (1971). The Growth of Economic Thought, Duke University Press.

Stevenson B and Wolfers J (2008). 'Economic growth and subjective well-being: reassessing the Easterlin paradox', NBER working papers, no 14282.

Stiglitz J, Sen, A and Fitoussi J-P (2010). Mis-measuring Our Lives, New Press.

Sutcliffe J (1926). The National Dividend, Melbourne University Press.

Treasury (1973). 'Economic growth: is it worth having?', Treasury Economic Paper, no 2, June.

Trewin D (1998). 'A framework for the presentation of indicators of national progress', in R Eckersley (ed) Measuring Progress, CSIRO publishing: 109-121.

Vaggi G and Groenewegen P (2003). A Concise History of Economic Thought, Palgrave Macmillan, London.

Veenhoven R (1996). 'Happy life-expectancy: a comprehensive measure of quality-of-life in nations', Social Indicators Research, vol 39: 1-58.

Wenzel T (2009). Beyond GDP - Measuring the Wealth of Nations, GRIN, Germany. 